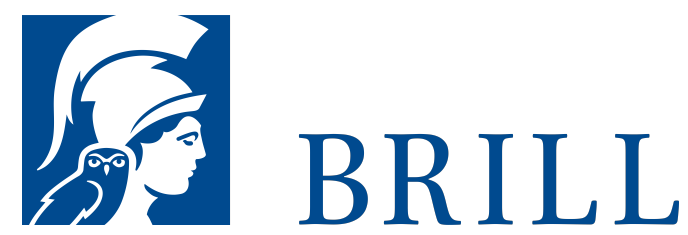

\title{
Wittgenstein and Normative Inquiry
}

Editors: Mark Bevir and Andrius Gališanka

Wittgenstein and Normative Inquiry examines the relevance of Ludwig Wittgenstein's philosophy for ethics, aesthetics, political philosophy, and religion. It analyzes the intellectual contexts which shaped Wittgenstein's normative thought, traces his influences, and presents contemporary uses of his philosophy in normative fields.

The chapters focus on the nature of normative inquiry. Together, they present a Wittgensteinian approach to normative inquiry, which, while broad and contested, stands in contrast to dominant deductive approaches. Arguing to normative conclusions by showing family resemblances, drawing analogies, using persuasion, appealing to naturalist arguments, authors and Wittgensteinians discussed by them expand our notion of normative inquiry.

\section{Readership}

All interested in the nature of normative inquiry (ethics, moral philosophy, political philosophy, aesthetics, religion), and the relevance of Ludwig Wittgenstein's philosophy to these fields.

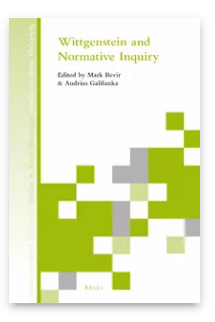

Pages: viii, 220 pp.

Language:

English

Subjects: Ethics

\& Moral

Philosophy, Philosophy, 19th \& 2oth Century

Philosophy, Philosophy, Philosophy of Religion, Philosophy, Social \&

Political

Philosophy, Philosophy

Publisher: Brill

Series:

Studies in Moral Philosophy,

Volume: 9

E-Book (PDF)

Released online: 10 Jun 2016

ISBN: 978-90-

04-32410-7

List price

USD $\$ 157.00$

Hardback

Publication date: 23 Jun 2016 
Mark Bevir, D.Phil., Oxford University, is Professor of Political

Science at the University of California, Berkeley. He has published on political theory, public policy, and philosophy of the social sciences, including his latest book, $A$ Theory of Governance (2013).

Andrius Gališanka, Ph.D., University of California, Berkeley, is Assistant Professor of Politics and International Affairs at Wake Forest University. He has published on political theory and philosophy of the social sciences.

For more information see brill.com

Order information: Order online at brill.com +44330 3330049 | customerservices@brill.com Submission information: brill.com/authors

Titles published by Brill | Fink, Brill | mentis or Brill | Schöningh: +49(o)71 5413279216 | brill@brocom.de 